\title{
Association of Vitamin D Receptor Ggene Ppolymorphisms and Type 1 diabetes in Egyptian Population.

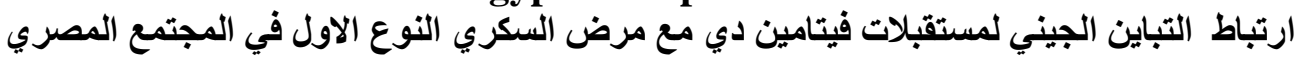

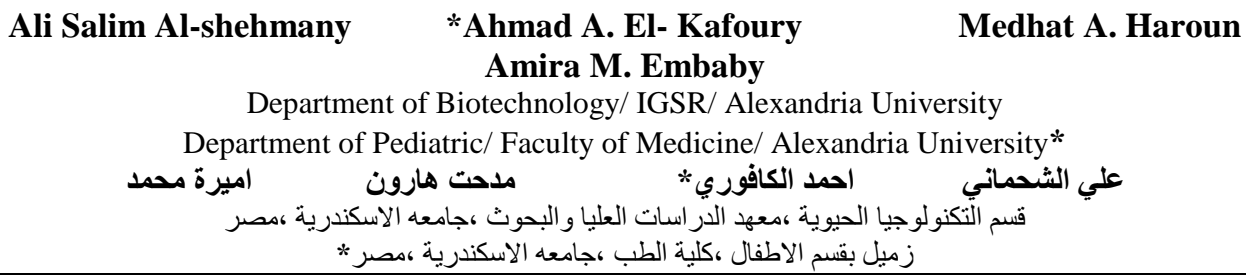

\begin{abstract}
The human vitamin D receptor (VDR) gene is located on chromosome 12q12-q14, and four common nucleotide polymorphisms have been identified. Several studies have found a relationship between polymorphisms of the (VDR) gene and development of type 1 diabetes (T1DM). The association of VDR polymorphisms and susceptibility to T1DM in the Egyptian population were examined in 60 individuals with type 1 diabetes and compared with healthy 60 persons. Single nucleotide polymorphisms (SNP) genotyping was performed using PCR and BsmI and FokI, by using two techniques, allele specific PCR technique and restriction fragment length polymorphism - PCR (RFLP-PCR). Data were analyzed using the chi square. The result approved that the genotype TA in SNP FokI was risk factor among type 1 diabetes mellitus patients combination which conferred strongest susceptibility to T1DM $(\mathbf{P}=0.004)$ while the SNP BsmI did not showed any significance between cases as compared with control $(P=0.493)$. The results of the current study indicated that VDR polymorphisms are associated with increased risk of T1DM in the Egyptian population. The difference in the association of the aforementioned SNPs variants with T1DM among different populations may be attributed to the presence of multiple susceptibility alleles.
\end{abstract}

Keywords: Vitamin D receptor, Genotype, Type 1 diabetes, Genetic susceptibility, SNP, BsmI, FokI

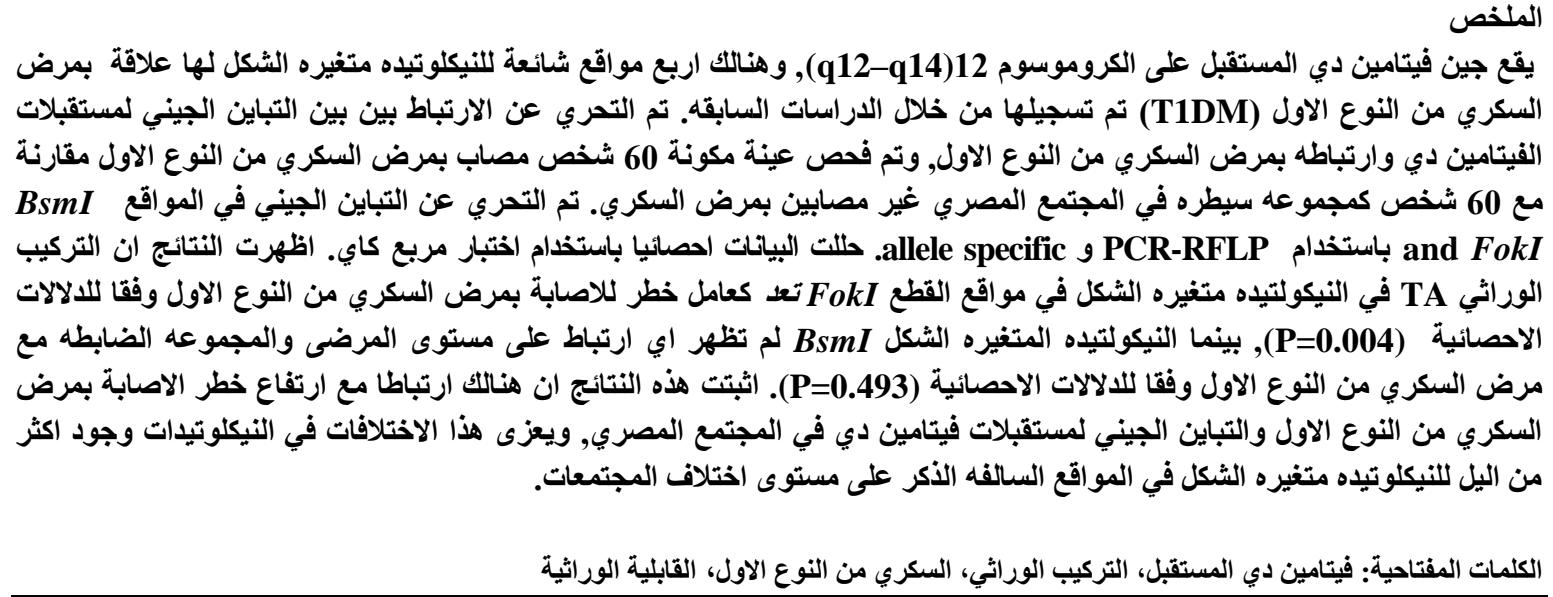

Introduction

Type 1 diabetes mellitus (T1DM) results from $\beta$-cell destruction, usually leading to absolute insulin deficiency. Testing for islet-cell antibodies (ICA) or other autoantibodies (antibodies to glutamic acid decarboxylase [anti-GAD], insulin, and to the tyrosine phosphatase IA-2) in serum may be helpful if establishing the diagnosis is important; a positive result is indicative of immune-mediated or type 1A diabetes [1]. Relationship between the vitamin D receptor (VDR) gene and T1DM has been noted in several populations [2-4] has been recognized for its immunomodulatory effects [5], and action on insulin secretion [6-9]. This molecule has been recognized for its acts through activation of the (VDR) that is encoded by a gene located in chromosome 12q12 [10]. Several polymorphisms have been described for the VDR gene [11]. Most studied are ApaI, BsmI, FokI, and TaqI. The VDR FokI polymorphism in exon 2 leads to an 
alternative transcription initiation site, resulting in a VDR protein with addition of three amino acids $[12,13]$. The VDR BsmI polymorphism is located in the intron between exon 8 and 9 and has no established functional role as of yet [13].

The aim of this study was to determine the association of T1DM with the two SNPs (SNP T / A rs\#2228570

\& SNP G / A rs\#1544410) in - vitamin D receptor to the susceptibility to type 1 diabetes in the Egyptian population.

\section{Materials and methods}

\section{Study populations}

A total of 60 type 1 diabetic patients ( 25 males $/ 35$ females) mean age \pm SD 11.2 $\pm 3.7,60$ healthy individuals (33 males / 27 females) mean age \pm SD $27.2 \pm 6.4$, family history ( 25 positive/ 35 negative to family history, disease onset (years) mean \pm SD 5.3 \pm 3.5 , were enrolled in this study and recruited at the El-Shatby University Hospital, Faculty of Medicine Alexandria - University, Egypt. Patients diagnosed according to WHO criteria [14]. Patients had been diagnosed on the basis of classical clinical presentation, first-degree family history of diabetes, history of chronic diabetes complications, and treatment of diabetes. Healthy controls had no personal or first-degree history of diabetes and were free from T1DM. The Ethics Committees of participating universities and university hospitals approved the study, and informed consent was obtained from all participants.

Blood sampling was carried out, one $\mathrm{ml}$ of venous blood sample was collected in EDTA tubes from each individual (patient or healthy control) and was stored as whole blood at $-20^{\circ} \mathrm{C}$ for subsequent DNA isolation. Genomic DNA was isolated from whole blood according to Sambrook et al (1989) [15].

\section{Genotyping of vitamin D-receptor gene polymorphism}

Two SNPs (SNP T / A rs\#2228570 \& SNP G / A rs\#1544410) in vitamin D-receptor were genotyped among the participants group in this study.

In vitamin D-receptor gene was genotyped among the participants groups in this study. The vitamin Dreceptor SNPs (SNP T / A rs\#2228570 \& SNP G / A rs\#1544410) was amplified by polymerase chain reaction (PCR) using allele specific PCR technique and restriction fragment length polymorphism -PCR (RFLP-PCR) as shown in Table 1. Four primers for SNP (SNP T / A rs\#2228570) (two allele specific primers, forward, control and common reverse primer) were designed based on the nucleotide sequence of a partial fragment (retrieved from the online dbSNP) of the gene containing the target SNP. The PCR product in SNP G / A rs\#1544410 was digested using an appropriate restriction enzyme HhaI, The recognition site of HhaI is -GCGC- after using forward primer 5-CCTCACTGCCCTTAGCTCTG-3 and reverse primer 5TCTCACCTCTAACCAGCGGA-3as shown in table 1 to amplify the SNP G/A rs\#1544410, the target SNP localized in the nucleotide sequence representing the recognition site of this restriction enzyme. The polymorphism was visualized by separating the DNA fragments in a $2 \%$ agarose gel that was stained with ethidium bromide and illuminated by UV. To validate the PCR- allele specific and restriction fragment length polymorphism results as showed in figure 1 and figure 2 , all primers used in this study were newly designed using Primer Blast online programmed (http://www.ncbi.nlm.nih.gov/tools/primer-blast/). 


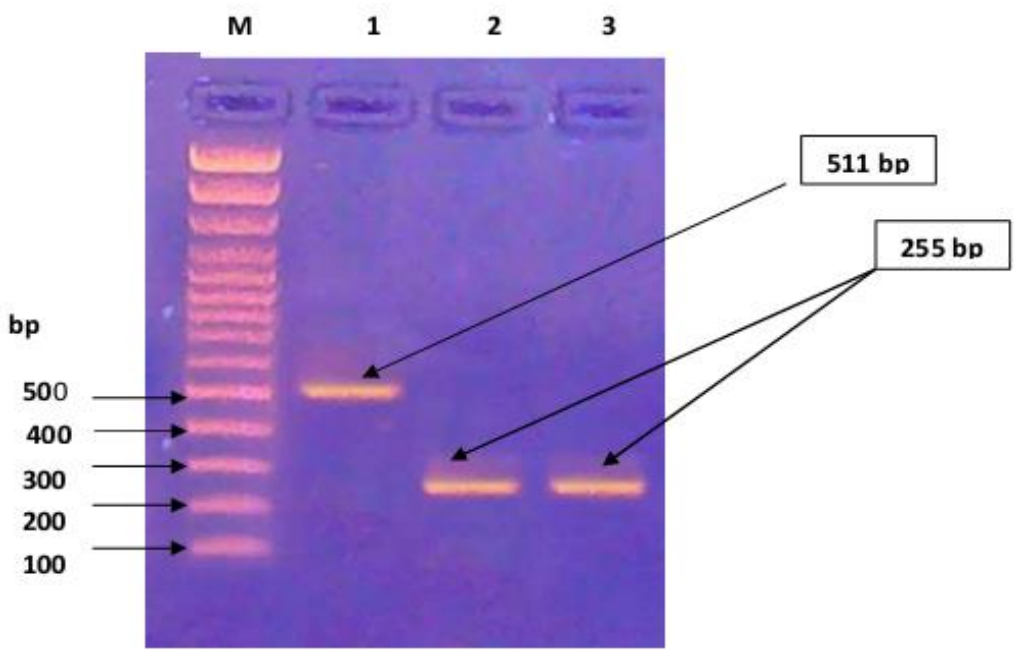

Fig. (1): Shows 2\% agarose gel electrophoresis for allele specific PCR for Vit.D SNP T>A rs\#2228570 (Fok1). M: 100 bp DNA ladder from GeneDire $X ®$. Lane1: PCR product upon using controls forward primer, Lanes 2 and 3: PCR products upon using allele specific $\mathbf{T}$ primer and allele specific A primer, respectively. Heterozygous genotype will give positive reaction upon using both allele specific primers. However, homozygous genotype will give positive reaction upon using only one of these allele specific primers.

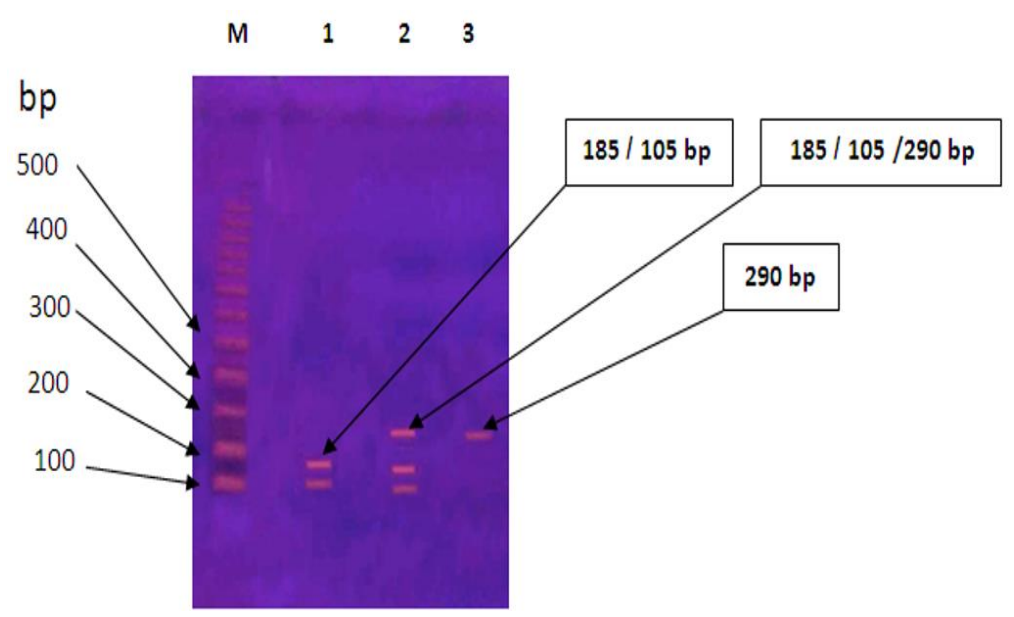

Fig. ( 2): Shows $2 \%$ agarose gel electrophoresis for RFLP- PCR for VitD Receptor SNP G>A (rs\#1544410). M: 100 bp DNA ladder from GeneDire $X ®$. Lane 1 represents a homozygous GG genotype as the G allele PCR products cleaved by FastDigest ${ }^{\circledR}$ HhaI into 104 bp and 185 bp. Lane 2 represents a heterozygous GA genotype as G allele PCR products cleaved by FastDigest ${ }^{\circledR}$ HhaI into 104 bp and 185 bp while A allele PCR products were still 290 bp. Lanes 3 represents a homozygous AA genotype after cleavage by FastDigest ${ }^{\circledR}$ HhaI still 290 bp.

\section{Statistical analysis of data}

Statistical analysis of the data was done to correlate genotype distribution and allele frequencies using SPSS package version 11 . The frequencies of alleles, genotypes in different groups were compared using the chisquared test (X2), T-test and Mann Whitney test were used to test the significance of results of quantitative variables. Odds ratio and 95\% confidence interval (95\% CIs) were calculated for different studied parameters. The confidence interval $(\mathrm{CI})$ at $95 \%$ was used to describe the amount of uncertainty associated with the samples [16, 17]. A $95 \%$ confidence level means that $95 \%$ of the intervals would include the parameter. The significance of the results was taken at the $\mathrm{P} \leq 0.05$ level of significance. 
Table (1): Primers sequences, PCR conditions, length of PCR products, restriction digestions and products of restriction digestion

\begin{tabular}{|c|c|c|c|c|}
\hline SNPs & Primers sequences & PCR Conditions & $\begin{array}{l}\text { Restriction } \\
\text { Digestion }\end{array}$ & $\begin{array}{l}\text { Size of PCR roducts } \\
\text { digestion products }\end{array}$ \\
\hline $\begin{array}{l}\text { VitD Receptor } \\
\text { Fok1 } \\
\text { SNP T /A } \\
(\text { rs\#2228570) } \\
* *\end{array}$ & $\begin{array}{l}\text { T-allele specific primer: } \\
\text { F1: 5-GCTTGCTGTTCTTACAGGGA T- } \\
3 \\
\text { A-allele specific primer: } \\
\text { F2:5-GCTTGCTGTTCTTACAGGGA } \underline{\text { A-3 }} \\
\text { Forward control primer: } \\
\text { 5- } \\
\text { CCTGACAGATGCAACATCTGAAAC-3 } \\
\text { Common reverse primer: } \\
\text { 5-GATGTGAAAAATGCAAGGGCTC-3 }\end{array}$ & $\begin{array}{l}\text { An initial } \\
\text { denaturation at } \\
95^{\circ} \mathrm{C} \text { for } 5 \text { min } \\
- \text { Then, } 30 \text { cycles } \\
\text { each cycle consisted } \\
\text { of denaturation at } \\
94^{\circ} \mathrm{C} \text { for } 60 \mathrm{~s}, \\
\text { annealing at } 50^{\circ} \mathrm{C} \\
\text { for } 30 \mathrm{~s} \text { and } \\
\text { extension at } 72^{\circ} \mathrm{C} \\
\text { for } 30 \mathrm{~s} . \\
- \text { A final extension at }^{\circ} \mathrm{C} \text { for } 10 \mathrm{~min} . \\
\end{array}$ & - & $\begin{array}{l}\text { Allele T: } 255 \text { bp Allele } \\
\text { A: } 255 \text { bp } \\
\text { Control fragment: } 499 \\
\text { bp }\end{array}$ \\
\hline $\begin{array}{l}\text { VitD Receptor } \\
\text { BsmI } \\
\text { SNP G/A } \\
(\text { rs\#1544410)* } \\
*\end{array}$ & $\begin{array}{l}\text { Forward primer: } \\
\text { 5-CCTCACTGCCCTTAGCTCTG-3 } \\
\text { Reverse primer: } \\
\text { 5- TCTCACCTCTAACCAGCGGA-3 }\end{array}$ & $\begin{array}{l}\text { An initial } \\
\text { denaturation at } \\
95^{\circ} \mathrm{C} \text { for } 5 \mathrm{~min} \\
- \text { Then, } 30 \text { cycles } \\
\text { each cycle consisted } \\
\text { of denaturation at } \\
94^{\circ} \mathrm{C} \text { for } 60 \mathrm{~s}, \\
\text { annealing at } 50^{\circ} \mathrm{C} \\
\text { for } 30 \mathrm{~s} \text { and } \\
\text { extension at } 72^{\circ} \mathrm{C} \\
\text { for } 30 \mathrm{~s} \text {. } \\
-{ }^{-A} \text { final extension at } \\
7^{\circ} \mathrm{C} \text { for } 10 \mathrm{~min} .\end{array}$ & $\begin{array}{l}\text { PCR } \\
\text { product was } \\
\text { digested } \\
\text { with HhaI } \\
\text { Fast digest } \\
\text { enzyme . } \\
\text { Total } \\
\text { volume of } \\
\text { digestion } \\
\text { reaction } \\
\text { mixture (30 } \\
\mu \mathrm{l}) \\
\text { contained: } \\
20 \mu \mathrm{l} \text { of PCR } \\
\text { product, } 1 \\
\mu \mathrm{l} \text { of HhaI } \\
(\text { Fast digest) } \\
\text { enzyme, } 3 \\
\mu \mathrm{l} \text { of } 10 \mathrm{X} \\
\text { buffer, } 1 \mu \mathrm{\mu l} \\
\text { of BSA and } \\
5 \mu \mathrm{l} \\
\text { nuclease } \\
\text { free water. } \\
\text { This } \\
\text { mixture } \\
\text { incubated } \\
\text { at } 37^{\circ} \mathrm{C} \text { for } \\
20 \text { minutes. }\end{array}$ & $\begin{array}{l}\text { PCR product: } 290 \text { bp } \\
\text { Restriction digestion } \\
\text { products : } \\
\text { 104 bp and } 185 \text { bp } \\
\text { Allele G: } 104 \text { bp and } 185 \\
\text { bp } \\
\text { Allele A: } 290 \mathrm{bp}\end{array}$ \\
\hline
\end{tabular}




\section{Results and Discussion}

This study demonstrates that VDR gene polymorphisms are associated with an increased risk of T1DM in Egyptian population which would be explained by differences in BsmI and Fok1 genotype distribution between T1DM patients and control group The present results revealed that the allele and genotypic distributions of GG, AA and GA were convergent, also did not showed significance according to the statistical analysis for the SNP BsmI G/A (rs\#1544410). On the other hand, there was a statistical significant difference between the two groups $\left(\mathrm{P}=0.004^{*}\right)$ of the SNP Fok1 T/A (rs\#2228570). The results showed that TA genotype distributions greater than TT and AA genotype according to the statistical analysis and this consider is a risk factor among T1DM patients as shown in Table (2).

Table (2): Vitamin D-receptor gene polymorphism and allele frequencies among diabetic patients and their control

\begin{tabular}{|c|c|c|c|c|c|c|}
\hline \multirow{2}{*}{$\begin{array}{c}\text { Gene } \\
\text { polymorphism }\end{array}$} & \multicolumn{2}{|c|}{ Cases } & \multicolumn{2}{|c|}{ Control } & \multirow[t]{2}{*}{ Significance } & \multirow[t]{2}{*}{ OR $(95 \%$ CI $)$} \\
\hline & No. & $\%$ & No. & $\%$ & & \\
\hline \multicolumn{7}{|l|}{ BsmI G/A } \\
\hline GG & 8 & 13.3 & 4 & 7.1 & $X^{2}=1.414$ & -- \\
\hline $\mathbf{A A}$ & 13 & 21.7 & 11 & 19.6 & $P=0.493$ & $0.6(0.1-3.1)$ \\
\hline GA & 39 & 65.0 & 41 & 73.2 & & $0.5(0.1-1.9)$ \\
\hline \multicolumn{7}{|l|}{ allele frequencies } \\
\hline G & 60 & 0.24 & 60 & 0.17 & & ------------. \\
\hline A & & 0.76 & & 0.83 & & \\
\hline Fok1 T/A & & & & & & $95 \%$ CI for \\
\hline TT & 16 & 26.7 & 7 & 11.7 & $X^{2}=33.700$ & difference: \\
\hline $\mathbf{A A}$ & 21 & 35.0 & 12 & 20.0 & $\mathbf{P}=0.004 *$ & (-46.473961; \\
\hline $\mathbf{A T}$ & 23 & 38.3 & 41 & 68.3 & & 46.473961) \\
\hline \multicolumn{7}{|l|}{ allele frequencies } \\
\hline $\mathbf{A}$ & & 65 & & 54.1 & & ------------ \\
\hline & & & 60 & & & \\
\hline $\mathbf{T}$ & & 55 & & 45.9 & & \\
\hline
\end{tabular}

In previous study Lemos et al.(2008) [18] suggested that the single nucleotide polymorphisms of the VDR gene are unlikely to contribute significantly to T1DM susceptibility in both loci in the Portuguese population. Nejentsev, et al. (2002) [19] indicated that common sequence variation in the VDR gene has no major effect in T1DM in both loci in the U.K populations. Otherwise Ban et al.[4] found that there is significantly higher prevalence in the VDR-FokI $\mathrm{T} \geq \mathrm{C}$ (rs\#10735810) genotype, the $\mathrm{F}$ allele / the FF genotype in the patients compared to the controls. They suggested that the VDR initiation codon polymorphism influences genetic susceptibility to T1DM among the Japanese. On the other hand, Wang et al.(2012)[20] suggested that FokI polymorphism in the VDR gene is not associated with T1DM especially in East Asians population, while Bsm I polymorphism in the VDR gene was associated with T1DM risk, especially in East Asians population. The apparent discrepancies between this study and other studies could be a result of the effect of ethnic differences related to the distribution of VDR polymorphisms in these populations, as well as to interactions with other genetic or environmental factors involved in the pathogenesis of type 1 diabetes mellitus.

\section{References}

1. AMERICAN DIABETES ASSOCIATION. (2008). Diagnosis and classification of diabetes mellitus. Diabetes Care 31 Suppl 1. S55-60.

2. Chang, T.J., Lei, H.H., Yeh, J.I., Chiu, K.C., Lee, K.C., Chen, M.C., Tai, T.Y., and Chuang, L.M. (2000). Vitamin D receptor gene polymorphisms influence susceptibility to type 1 diabetes mellitus in the Taiwanese population. Clin Endocrinol (Oxf). 52: 575-580. 
3. Pani, M.A., Knapp, M., Donner, H., Braun, J., Baur, M.P., Usadel, K.H., and Badenhoop, K. (2000). Vitamin D receptor allele combinations influence genetic susceptibility to type 1 diabetes in Germans. Diabetes. 49: 504507.

4. Ban, Y., Taniyama, M., Yanagawa, T., Yamada, S., Maruyama, T., and Kasuga, A. (2001). Vitamin D receptor initiation codon polymorphism influences genetic susceptibility to type 1 diabetes mellitus in the Japanese population. BMC Med Genet. 2: 7.

5. Manolagas, S.C., Hustmyer, F.G., and Yu, X.P. (1990). Immunomodulating properties of 1,25-dihydroxyvitamin D3. Kidney Int Suppl. 29: 9-16.

6. Norman, A.W., Frankel, J.B., Heldt, A.M., and Grodsky, G.M. (1980). Vitamin D deficiency inhibits pancreatic secretion of insulin. Science. 209: 823-825.

7. Gedik, O., and Akalin, S. (1986). Effects of vitamin D deficiency and repletion on insulin and glucagon secretion in man. Diabetologia. 29: 142-145.

8. Boucher, B.J., Mannan, N., Noonan, K., Hales, C.N., and Evans, S.J. (1995). Glucose intolerance and impairment of insulin secretion in relation to vitamin D deficiency in east London Asians. Diabetologia. 38: 1239-1245.

9. Chiu, K.C., Chu, A., Go, V.L., and Saad, M.F. (2004). Hypovitaminosis D is associated with insulin resistance and beta cell dysfunction. Am J Clin Nutr. 79: 820-825.

10. Haussler, M.R., Whitfield, G.K., Haussler, C.A., Hsieh, J.C., Thompson, P.D., Selznick, S.H., Dominguez, C.E., and Jurutka, P.W. (1998). The nuclear vitamin D receptor: biological and molecular regulatory properties revealed. J Bone Miner Res. 13: 325-349.

11.Zmuda, J.M., Cauley, J.A., and Ferrell, R.E. (2000). Molecular epidemiology of vitamin D receptor gene variants. Epidemiol Rev. 22: 203-217.

12. Gyorffy, B., Vasarhelyi, B., Krikovszky, D., Madacsy, L., Tordai, A., Tulassay, T., and Szabo, A. (2002). Gender-specific association of vitamin D receptor polymorphism combinations with type 1 diabetes mellitus. Eur J Endocrinol. 147: 803-808.

13. Uitterlinden, A.G., Fang, Y., Van Meurs, J.B., Pols, H.A., and Van Leeuwen, J.P. (2004). Genetics and biology of vitamin D receptor polymorphisms. Gene. 338: 143-156.

14. American Diabetes Association, Alexandria, Virginia. (2003). Report of the expert committee on the diagnosis and classification of diabetes mellitus. Diabetes Care. 26 Suppl 1: 5-20.

15. Sambrook, J., Frisch, E.F., and Maniatis, T. (1989). Molecular cloning: A laboratory Manuel,2 nd edition. Cold spring Harbor laboratory press, New York.

16. Greenfield, B., Henry, M., Weiss, M., Tse, S.M., Guile, J.M., Dougherty, G., Zhang, X., Fombonne, E., Lis, E., Lapalme-Remis, S., Harnden, B. (2008). Previously suicidal adolescents: predictors of six-month outcome. J Can Acad Child Adolesc Psychiatry. 17: 197-201.

17. Szumilas, M. (2010). Explaining odds ratios. J Can Acad Child Adolesc Psychiatry. 19: 227-229.

18. Lemos, M.C., Fagulha, A., Coutinho, E., Gomes, L., Bastos, M., Barros, L., Carrilho, F., Geraldes, E., Regateiro, F.J., and Carvalheiro, M. (2008). Lack of association of vitamin D receptor gene polymorphisms with susceptibility to type 1 diabetes mellitus in the Portuguese population. Hum Immunol. 69: 134-138.

19. Nejentsev, S., Cooper, J.D., Godfrey, L., Howson, J.M., Rance, H., Nutland, S., Walker, N.M., Guja, C., Ionescu-Tirgoviste, C., Savage, D.A., Undlien, D. E., Ronningen, K. S., Tuomilehto-Wolf, E., Tuomilehto, J., Gillespie, K. M., Ring, S. M., Strachan, D. P., Widmer, B., Dunger, D., Todd, J. A. (2004). Analysis of the vitamin D receptor gene sequence variants in type 1 diabetes. Diabetes. 53: 2709-2712.

20. Wang, Q., Xi, B., Reilly, K.H., Liu, M., and Fu, M. (2012). Quantitative assessment of the associations between four polymorphisms (FokI, ApaI, BsmI, TaqI) of vitamin D receptor gene and risk of diabetes mellitus. Mol Biol Rep. 39: 9405-9414. 